\title{
THE PECULIARITIES OF THE MINERAL COMPOSITION OF THE DIAMOND BEARING ECLOGITES FROM THE UDACHNAJA KIMBERLITE PIPE.
}

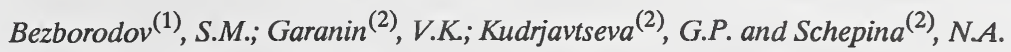 \\ (1) SPC "Jakutalmaz", 678189, Udachni, Jakutskaja ASSR, USSR; (2) Geological Department of Moscow State \\ University, 119899, Lenin's Hills, Moscow, USSR.
}

The complex study of the mineralogjaal composition of tht diamond bearing eclogites, 67 xemoliths from the Udachnaja kimber lite pipe, including 15 nodules of orange garnets, is carried out by the method of uptical and scanning electron microscopy, woloured cathodolurinescence (CL), electron-probe analysis, optical spectroscopy and colorymetry. All the samples of the investigated eclogites have the traces of cataclasis and recurrent metasomatic influence of fluids, causing the intensive replaremrat of garnet by hydrogarnet and by complicated mineral association ( diopsille - amphibole - green spinel) and decomposition of clinopyroxene and plagioklase, considerably calcium pyroxene and serpentine.

The diamond crystals in the studied collection of eclogites are uf octahedral shape with the microrelief of dissolving and, very seldom, with poorly developed elges of rhombodidecahedron. The diamond crystals of the cubic habitus are discovered in one of the studied samplés. The sizes of crysl.als vary from $20 \mu$ to $6 \mathrm{~mm}$ and, in this case, several diamond crystal of different sizes are discovered in numerous xenoliths. About 30 diamond crystals on the surface of eclogites are studied by the method of coloured cathodoluminescence on the basis of optiad microscopy. Most of them have the blue colour of the cathodoluminescence (with high concentration of nitrogen, type I), with the exception of several samples, where together with the crystals of blue CL-colour, the ones of clearly marked yellow colour (type IIa and type IIb) are discovered. The discoveries like these one may have proved the different genetic nature of the diamond crystal in mue xenolith.

The rowk forming garnet and clinopyroxene are the "conservatives"of the didmona orystals included into thrm and they provide the conservation of even small crystals of diamond (size uf : :everal microns) when they are brought up to the surface i) the kimberlite magma.

In the optical absorption spectra of the garnets, the observed lines of absurption are facilitated by the chromophornic centres $F e^{* \ldots}$, Fen, and $C r^{* \ldots}$ and are also connected with

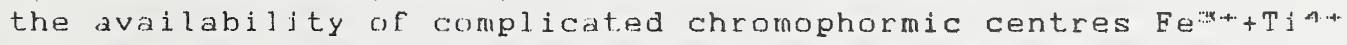
as was discovered by the method of optical spectroscopy and colorimetry. Their correlation and concentration facilitate the different shadis of colour of garnets from the investigated exlogjtes, from dark yellow-orange tu light yellow-orange. On the modified liagram of colour in the colorimetric coordinates pe. and $\lambda_{\text {w: }}$ the points of (o)lour of the investigated garnets are in the field of the diamond bearing magnesian-ferrous, disthene and corundum eclogites.

In all the investigated samples, garnet refers to pyropeal mandine-yrossular row with wide range of pyrope ( 29.3-75.5 mol. 1 ), almandine ( $13.3-46.4$ mol.z) and grossular ( $0.7-52.0$ mol.q) rinals. The practically full absence of chrome and increased content of titanium (to 0.67 wt.q $\mathrm{TiO}_{2}$ ) and sodium (t.o) 
0.63 wt. $\% \mathrm{Na}_{2} \mathrm{O}$ ) are charactéristic for garnets. With the increase of yrosiular minal in garnet and lecrease of pyrope one, the regular change of colorimetric garnet parameters takes place : the value $p_{c}$ decreases and dark-yellow-orange colour is ahanged into Iight-yeliow-orange. Accordiny to J.Dawson and W. Stephens (1975) classification all garnets refer to four groups titanium pyrope, calaium pyrope-almandine, titanium and calcium magnesian almandine, pycope-grossular almandine.

As a result of usage of the data base on garnet from ec$10 g$ iles and the application of discriminant analysis (Garanin et al , 1990), garnets were considered as a mineral from ilmenite-rutile diamond bearing magnesian-ferrous eclogites, bimineral diamond bearing magnesian-ferrous eclogites, aluminous (corundum and disthene) eclogites, magnesian ilmenite-rutile diamond bearing eclogites. The group magnesianfferrous of eclogites is also marked out where garnets is sharply differrnt from the known ores by the analysis by high contents of iron ( to 1.51-1.95 wt. 8 Fe.. 0 and 12.16-14.35 wt. 8 FeO), magnesium (17.419.57 wt. 8 MgO) and low cuntent of calcium(2.47-3.06 wt.o CaO).

Not only the typomorphism of the garnet composition but also that of alinopyroxene is studied. According to the classification of W.Stephens and J.Dawson (1977) the studied clinopyrozenes are referred to diopside, jadeitic diopside and nmphacite. The studifd pyroxenes are referrea to the group of pyroxenites, disthene and corumbum diamond bedring eclogites and biminer., d a amona bearing eclugites by using the data base on clinopyroxene from eclogites; and their chemico-gerietical cliassificition and methods of discriminant analysis(Garanin et al., 1990). All of them tefer to isumorphic row diopside-jadeiteforrusilite (tclinoenstatite). In this case diopside and jadeit. minals constitute together more than 60 mol.o. The ratio $\mathrm{Ca} /(\mathrm{Ca}+\mathrm{Mg})$ constitute 41-56. The evaluation of crystallization temperatures of eclogites is carried out for all the samples, in which clinopyroxene is analysed.

The variation of temperatures, using the geothermometer of Ellis-Green (1979), are about $1021-1137^{\circ} \mathrm{C}$ under the pressure of $40 \mathrm{kbat}$. The composition of the accessory minerals in all the varieties of eclogites was also studied : corunduru (sapphire), disthenr, ilmenite, rutile, sulfide pyrrhotine-pentlanditechalcopyrite( +jerphisherite) association. The wide spreading of ilmenite-rutile intergrowthes in magnesian eclogites should be nuted.

Two main evolution trends have been established for eclogites: magnesian - magnesian-calcium and magnesian - magnesianferrous. They are clearly shown in the regular change of corpositiun:s and different. schemes of isomorphic replacement in garnets: $M g \leftrightarrow \rightarrow C a$ and $M g \leftrightarrow \rightarrow E e^{-m+\cdots}$.

The differences in the composition of garnets and pyroxenes - inclusions in diamond, on the one hand, and rock forming garnets and pyroxenes of eclogites, containing diamond, on the other hand, were established. The new criteria for the searching of the kimberlite rocks on the basis of the typomorphism of the rock forming garnets and pyroxenes from the diamond bearing rrolugites are offered and different genetic models of the diamond bearing eclogites and their role in the general evolution of the both mantle and crustal rocks are discussed.

References :

1. Dawson,J.B., and Stephens,W.E.(1975) Statistical analysis of garnets from kimberlites and associated senoliths. J.Geol.,83,589-607 
2. Ellis,D.J., and Green,D.H. (1979) An experimental study of the effect of $\mathrm{Ca}$ upon garnet-clinopyroxene exchange equilibria. Contrib.Miner.\& Petrol.,71,13-22

3. Garanin, V.K., Kudrjavtseva, G.P., Mikhailichenko, O.A., and Marfunin, A.S. (1990) The inclusions in diarnond and diamond bearing rocks, $272 \mathrm{p} .$, Moscow University, Moscow

4. Stephens,W.E., and Dawson,J.B.(1977) Statistical comparison between pyroxenes from klmberlitez and their ascodiated renoliths. J.Geol.,85, 433-449 